\title{
PENGARUH MOTIVASI DAN DISIPLIN KERJA TERHADAP PRODUKTIVITAS KERJA PEGAWAI PADA DINAS PERKEBUNAN KABUPATEN MUSI BANYUASIN
}

\author{
Ellisyah Mindari \\ Sekolah Tinggi Ilmu Ekonomi Rahmaniyah \\ ellisyahmindari@gmail.com
}

\begin{abstract}
Abstrak. Penelitian dilaksanakangunamengkaji pengaruh motivasi $\left(x_{I}\right)$ dan disiplin kerja $\left(x_{2}\right)$ terhadap produktivitas kerja $(y)$ pegawai, baik secara simultan maupun parsial. Metode penelitian yaitu survei (kuantitatif). Menurut tingkat eksplanasi, rumusan masalahnya adalah asosiatif berbentuk hubungan kausal/sebab akibat. Data diuji validitas, reliabilitas, analisis regresi ganda, koefisien determinasi, uji serentak dan parsial. Didapat persamaan regresi gandaY $=20,956+0,334 x_{1}+0,133 x_{2}$. Nilai koefisien determinan 0,307 artinya y dijelaskan oleh $x_{1}$ dan $x_{2}$ sebesar 30,7\%, sisanya 69,3\% dijelaskan faktor yang lain. Berdasarkan uji f diperoleh $F_{\text {hitung }}$ $17,539>F_{\text {tabel }}$ 3,112 maknanyax 1 dan $x_{2}$ secara simultan berpengaruhpaday dengantaraf signifikan $0,000<\alpha(0,05)$,sehinggaadapengaruh signifikan. Variabel motivasi memiliki nilai thitung 5,407 > $t_{\text {tabel }} 1,991$ maknanya secara parsial ada pengaruh $x_{1}$ terhadap y dan nilai Sig $t 0,000<\alpha(0,05)$ artinya ada pengaruh signifikan. Sementara itu, nilai thitung variabel disiplin kerja $1,488<t_{\text {tabel }} 1,991$, sehingga tidak terdapat pengaruh parsialx 2 terhadap $y$ dan nilai Sig t 0,141> $\alpha(0,05)$, sehingga $x_{2}$ tidak berpengaruh signifikan.

Kata kunci: Disiplin Kerja, Produktivitas Kerja, Motivasi.
\end{abstract}

Abstract. This study aims to analyze the effect of motivation $\left(x_{1}\right)$ and work discipline $\left(x_{2}\right)$ on work productivity $(y)$ of employees, either together or partially. The research method uses survey research methods (quantitative). According to the level of explanation, formulation of the problem is associative with the form of a causal relationship. The data were tested for validity, reliability, multiple regression analysis, determinant coefficients, $F_{\text {test }}$ and $t_{\text {test. }}$. The multiple regression equation is $Y=20,956+0,334 x_{1}+0,133 x_{2}$. Value of the determinant coefficient is 0,307, which means that $y$ is explained by $x_{1}$ and $x_{2}$ of $30.7 \%$, while $69.3 \%$ is explained by other factors. The results of the ftest show that $F_{\text {count }} 17,539>F_{\text {table }} 3,112$ which means that there is an effect of $x_{1}$ and $x_{2}$ together on $y$ and $a$ significant value of $0,000<\alpha(0,05)$ which indicates that there is a significant effect. The motivation variable has a $t_{\text {count }}$ value of 5,407 > $t_{\text {table }}$ 1,991 which means that there is a partial effect of $x_{1}$ on $y$ and the value of Sig $t$ is $0,000<\alpha(0,05)$ meaning that there is a significant effect. Meanwhile, $t_{\text {count }}$ value of the work discipline variable is 1,488 $<t_{\text {table }} 1,991$ which can be interpreted that there is no partial effect of $x_{2}$ on $y$ and the value of Sig $t$ is $0,141>\alpha(0,05)$ which means that $x_{2}$ has no significant effect.

Keywords: Work Discipline, Work Productivity, Motivation. 


\section{PENDAHULUAN}

Setiap perangkat daerah dituntut untuk dapat mengoptimalkan sumber daya manusia dalam mencapai tujuannya karena peran manusia sangat strategis dan vital. Setiap individu memiliki karakter yang berbeda akibat perbedaan pendidikan, kemampuan, watak dasar dan faktor lainnya. Keberagaman perilaku tersebut akan mempengaruhi jalannya aktivitas suatu instansi, tidak hanya berpengaruh pencapaian tujuan organisasi saja, tetapi juga mempengaruhi pelayanan kepada masyarakat.

Pengelolaan sumber daya manusia harus dilakukan perangkat daerah supayamenghasilkan produktivitas kerja tertinggi, sehingga mampu mendorong kinerja instansi secara maksimal. Produktivitas kerja dimaknai sebagai hasil maksimal yang terlahir dari proses kerja seseorang. Faktor manusia mempunyai peran vital dalam pencapaian hasil sesuai dengan tujuan perangkat daerah. Sesempurna apapun peralatan dan perlengkapan kerja bila tidak diimbangi dengan tenaga manusia, maka dalam proses produksi dan pencapaian tujuan tidak akan tercapai. Sehingga produktivias kerjadipengaruhi oleh motivasi serta disiplin kerja.

Perangkat daerah sebagai suatu organisasi adalah wadah kerjasama antara orangorang dalam upaya pencapaian tujuan, di mana di dalamnya ada pimpinan yang mempengaruhi orang lain untuk dapat bergerak dengan penuh sukacita dan semangat, ada juga bawahan yang termotivasi dengan menunjukkan usaha dan bekerja keras dalam pencapaian tujuan organisasi. Produktivitas kerja yang maksimal dapat dicapai bila pegawai mempunyai motivasi tinggi yang ditunjukkannya dalam bekerja.

Pencapaian tujuan perangkat daerah juga dipengaruhi faktor disiplin kerja. Mathis dan Jackson (2011:528) mengemukakan bahwa disiplin kerja merupakan pelatihan melaluiaturan yang terstruktur. Pegawai yang berdisiplin tinggi akan melakukan tugasnya dengan semaksimal mungkin demi tercapainnya produktivitas kerja dalam upaya mewujudkan tujuan perangkat daerah.

Berdasarkan observasi penulis pada Dinas Perkebunan Kabupaten Musi Banyuasin,tampak bahwa lingkungan kerja kurang nyaman, terdapat pegawai yang bekerja tanpa persiapan, menunda pekerjaan, malas dalam bekerja, pencapaian target kerja yang masih rendah, datang terlambat, ngobrol pada jam kerja, pulang lebih cepat, pelaksanaan kegiatan yang kurang maksimal, tidak selesainya beberapa pekerjaan, terlambatnya pelaksanaan kegiatan, bekerja bukan sesuai tugas pokok dan fungsinya, bekerja kurang terarah, kurang inisiatif,keinginan berkembang dan berprestasi yang masih rendah, pegawai baru agak sulit beradaptasi, barang inventaris kurang terawat.

Fenomena tersebut mendorong penulis untuk mengkaji lebih dalam permasalahan yang ada dengan batasan penelitian pada pengaruh simultan maupun parsial antara disiplin dan motivasi kerja pada produktivitas pegawai Dinas Perkebunan Musi Banyuasin.

\section{KAJIAN PUSTAKA}

\section{Konsep Produktivitas Kerja}

Produktivitas kerja olehHasibuan dalam Marsih dan Swarga (2020) didefinisikan sebagai komparasi antara hasil dan input, yaitu produk harus memilki peningkatan nilai atau metode pengerjaan lebih baik. Menurut Triton dalam Rampisela dan Lumintang (2020), produktivitas kerja merupakankomparasi hasil dengan total sumber daya yang dicurahkan. Selanjutnya, menurut Mathis dan Jackson (2011:9),productivity is a measure of the quality and quantity of work done, considering the cost of resources used. Senada dengan teori tersebut, Sulistiyani dan Rosidah dalam Kartika dan Khaerana (2019) mengungkapkan produktivitas berkaitan dengan hasil akhir, yaitu besaran hasil pada produksi.

Menurut Siagian dalam Supriyanto (2019), indikator produktivitas kerja meliputi kinerja, efisiensi waktu, kuantitas pekerjaan,etos kerja dan kedisiplinan.Tingkat produktivitas kerja juga dipengaruhi faktor pendidikan, sikap, keterampilan, 
mental,disiplin, etika kerja, gizi, motivasi, pendapatan, kesehatan, suasana kerja, relasi industrial Pancasila, manajemen, teknologi, jaminan sosial, fasilitas produksi,dan peluang prestasi (Sedarmayanti, 2017:343).Selanjutnya Nawawi dalam Oemar, Alamsyah dan Riansyah (2018) menyatakan bahwa sumber produktivitas adalah penggunaan pikiran, tenaga jasmani, waktu, ruangan dan material atau bahan.

\section{Konsep Motivasi}

Bergerak (movere) merupakan asal kata motivasi. Robbins dan Coulter (2010:109), mendefinisikan motivasi sebagai proses usahadengan memberikanindividu energi dan dorongan berkelanjutan untuk mencapai suatu tujuan. Hal serupa juga diungkapkan Rivai dan Sagala (2010:837),definisi motivasi yaitu rangkaiannilai serta sikap yang mempengaruhipencapaian tujuan spesifik setiap individu. Sholihat dalam Mustika (2020:130) mengartikan motivasi sebagai dorongan dari dalam ataupun luar individu untuk mewujudkan target ataupun tujuan yang telah ditetapkan sebelumnya, baik target individu maupun target kelompok.

Beberapa teori yang membahas tentang motivasi adalah teori Abraham Maslow, teori Clayton Alderter ERG (existence, relatedness, growth), teori Douglas McGregor, teori Herzberg, teori evaluasi kognitif, teori David McClelland, goal setting theory, teori efektivitas diri, reinforcement, equity theory, expectancy theory.McClelland dalam Mustika (2020:132) menyatakan terdapat tiga unsur kebutuhan manusia meliputi kebutuhan terhadap prestasi, kebutuhan berafiliasi dan kebutuhan terhadapkekuasaan.

\section{Konsep Disiplin Kerja}

Stewart dan Brown (2011:272), menyatakan bahwa pendidikan kesopanan, spiritualitas dan pendidikan karakter sebagai organizational efforts to correct improper behavior of employess.Rivai dan Sagala (2010:825),menyebutkan disiplin kerja ialah media manajer dalammenjalin komunikasisekaligus sarana untuk meningkatkan kesadaran pegawai agar lebih taat terhadap peraturan perusahaan. Perspektif daftar terkaitdisiplin kerja meliputidisiplin retributif, korektif,perspektif hakpribadi dan utilitarian.

Menurut Hasibuan dalam Ayu dan Sinaulan (2018),indikator disiplin kerja meliputi kemampuan,tujuan,pimpinan yang dapat menjadi contoh, balas jasa, pengawasan melekat, keadilan, ketegasan, sanksi, serta kemanusiaan.

\section{Kerangka Berfikir}

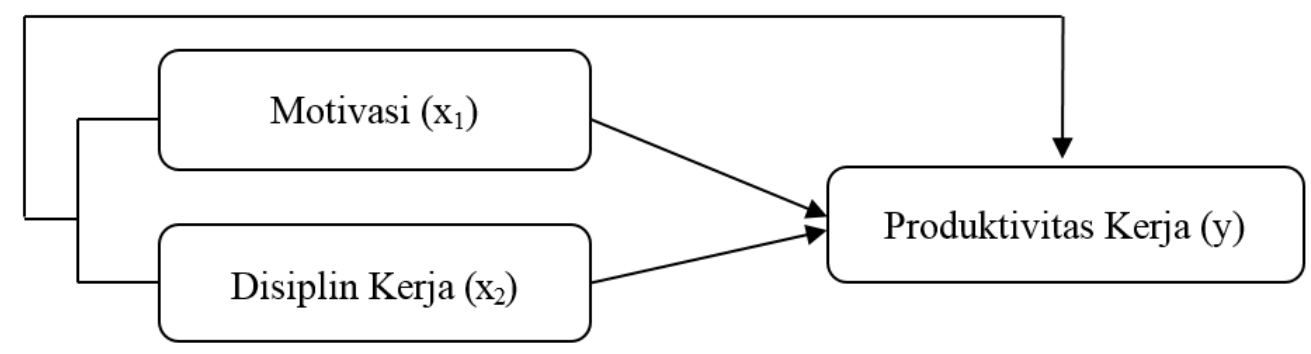

Gambar 1

Kerangka Pemikiran

\section{Hipotesis}

Hipotesis penelitian yaitu terdapat pengaruh simultan maupun parsial signifikan antara motivasi dan disiplin kerjaterhadap produktivitas kerja pegawai Dinas Perkebunan Musi Banyuasin 


\section{METODE PENELITIAN}

\section{Lokasi Penelitian}

Penelitian dilaksanakan di Dinas Perkebunan Kabupaten Musi Banyuasin dengan alamat Jalan Perjuangan Kel. Serasan Jaya Kecamatan Sekayu, Musi Banyuasin, Sumatera Selatan.

\section{Desain Penelitian}

Menurut tingkat kealamiahan (natural setting), penelitian berjenis kuantitatif berdasarkan metode surveiguna menghimpun data secaralangsung tanpa unsur buatan, kemudian dilakukan perlakuan dalam pengumpulan data. Menurut Sugiyono (2019:16) metode penelitian kuantitatif digunakan untukmengkaji sampel, menghimpun informasidengan instrumen khusus, kemudian dilanjutkan dengan analisis secara statistik untuk menguji hipotesis penelitian.

Menurut tingkat eksplanasi, rumusan masalah penelitian ini termasuk asosiatif berbentuk hubungan sebab akibat, dengan variabelindependen motivasi dandisiplin kerja, sertavariabel dependen berupa produktivitas kerja.

\section{Populasi dan Sampel}

Sebanyak 103 orang pegawai Dinas Perkebunan Kabupaten Musi Banyuasin merupakan populasi penelitian ini. Perhitungan sampel menggunakan rumus Yamane dalam Sugiyono (2019:137) dengan sampling error 5\%, diperoleh jumlah sampel sebanyak 82 orang (pembulatan dari 81,91).

\section{Sumber dan Teknik Pengumpulan Data}

Data berupa primer dan sekunder.Data dihimpunmelalui angket tertutup dengan sistem penilaian mengacu pada skala likert dan teknik dokumentasi bersumber dokumen resmi yang diperoleh dari Dinas Perkebunan Kabupaten Musi Banyuasin.

\section{Metode Analisis}

Kualitas data diuji tingkat validitas dan reliabilitas dengan bantuanIBM SPSS Statistic 24. Tahapan analisis kuantitatif meliputi analisis regresi ganda, analisis koefisien determinasi, uji $\mathrm{F}$ guna mengukurpengaruh simultandan uji t untuk pengaruh parsial.

\section{HASIL DAN PEMBAHASAN}

\section{Pengujian Validitas Data}

Kriteria pengujian validitas data menurut Machali (2015:158) adalah valid bila $r_{\text {hitung }}>r_{\text {tabel }}$ dan tidak valid ketika $r_{\text {hitung }}<r_{\text {tabel. }}$ Uji dua arah dengan $\alpha=5 \%, n=82$ menghasilkan Nilai $r_{\text {tabel }}$ 0,219.Metode cronbach's alpha penulis gunakan untuk menguji validitas data dengan hasil yaitu: 
Tabel 1

Hasil Uji Validitas

\begin{tabular}{|c|c|c|c|c|}
\hline No. & Item & $\begin{array}{l}\text { Corrected Item- } \\
\text { Total Correlation }\end{array}$ & $\begin{array}{c}\mathbf{r}_{\text {tabel }} \\
(\alpha=\mathbf{5} \%)\end{array}$ & $\begin{array}{l}\text { Hasil Uji } \\
\text { Validitas }\end{array}$ \\
\hline 1. & $\overline{x_{1} \_1}$ & 0,372 & 0,219 & Valid \\
\hline 2. & $\mathrm{x}_{1}-2$ & 0,605 & 0,219 & Valid \\
\hline 3. & $\mathrm{x}_{1}-\frac{1}{3}$ & 0,460 & 0,219 & Valid \\
\hline 4. & $\mathrm{x}_{1}{ }_{-}$ & 0,701 & 0,219 & Valid \\
\hline 5. & $\mathrm{x}_{1}-5$ & 0,613 & 0,219 & Valid \\
\hline 6. & $\mathrm{x}_{1}-6$ & 0,437 & 0,219 & Valid \\
\hline 7. & $\mathrm{x}_{1}-7$ & 0,667 & 0,219 & Valid \\
\hline 8. & $\mathrm{x}_{1}-8$ & 0,750 & 0,219 & Valid \\
\hline 9. & $x_{1} 9$ & 0,778 & 0,219 & Valid \\
\hline 10. & $\mathrm{x}_{1}-10$ & 0,363 & 0,219 & Valid \\
\hline 11. & $x_{1} 11$ & 0,706 & 0,219 & Valid \\
\hline 12. & $\mathrm{x}_{1}-12$ & 0,665 & 0,219 & Valid \\
\hline 13. & $\mathrm{x}_{2}{ }_{-}^{-1}$ & 0,739 & 0,219 & Valid \\
\hline 14. & $x_{2} 2$ & 0,903 & 0,219 & Valid \\
\hline 15. & $x_{2}{ }_{3}$ & 0,787 & 0,219 & Valid \\
\hline 16. & $\mathrm{x}_{2}-4$ & 0,857 & 0,219 & Valid \\
\hline 17. & $x_{2}-5$ & 0,672 & 0,219 & Valid \\
\hline 18. & $\mathrm{x}_{2}-6$ & 0,844 & 0,219 & Valid \\
\hline 19. & $x_{2}-7$ & 0,693 & 0,219 & Valid \\
\hline 20. & $x_{2}-8$ & 0,886 & 0,219 & Valid \\
\hline 21. & $\mathrm{y} 1$ & 0,669 & 0.219 & Valid \\
\hline 22. & $\mathrm{y} 2$ & 0,593 & 0,219 & Valid \\
\hline 23. & y3 & 0,593 & 0,219 & Valid \\
\hline 24. & y4 & 0,656 & 0,219 & Valid \\
\hline 25. & y 5 & 0,594 & 0,219 & Valid \\
\hline 26. & y6 & 0,565 & 0,219 & Valid \\
\hline 27. & $\mathrm{y}^{7}$ & 0,399 & 0,219 & Valid \\
\hline 28. & y8 & 0,604 & 0,219 & Valid \\
\hline 29. & y9 & 0,552 & 0,219 & Valid \\
\hline 30. & y 10 & 0,598 & 0,219 & Valid \\
\hline
\end{tabular}

Sumber: Data Hasil IBM SPSS Statistic 24, 2021

Berdasarkan hasil outputtersebut, setiap item instrument motivasi, disiplin kerja dan produktivitas kerja valid pada kriteria $\alpha=5 \%$, sehingga setiap item instrumen layak menjadi alat ukur valid dalam penelitian.

\section{Pengujian Reliabilitas Data}

Batas nilai kritis product moment $(\alpha)=0,6$ menurut Priyatno (2014:64), instrument reliabel ketikaalpha cronbach $\geq 0,6$, sedangkan tidak reliabel ketikaalpha cronbach $\leq 0,6$. Penggunaan metodealpha cronbachdimaksudkan untuk mengetahui nilaireliabilitas datasebagaimanaoutput berikut:

Tabel 2

Hasil Uji Reliabitas

\begin{tabular}{llrcc}
\hline No. & \multicolumn{1}{c}{ Variabel } & $\begin{array}{c}\text { Cronbach's } \\
\text { Alpha Item }\end{array}$ & $\begin{array}{c}\text { Nilai } \\
\text { Alpha }\end{array}$ & $\begin{array}{c}\text { Hasil Uji } \\
\text { Reliabilitas }\end{array}$ \\
\hline 1. & Motivasi $\left(\mathrm{x}_{1}\right)$ & 0,889 & 0,600 & Reliabel \\
2. & Disiplin Kerja (x2) & 0,942 & 0,600 & Reliabel \\
3. & Produktivitas Kerja (y) & 0,865 & 0,600 & Reliabel \\
\hline
\end{tabular}

Sumber: Data Hasil IBM SPSS Statistic 24, 2021 
Hasil output menunjukkan nilai alpha cronbach seluruh variabeldiatas 0,6, sehinggainstrumen reliabel untuk analisis selanjutnya.

\section{Analisis Regresi Berganda}

Pemilihan multiple regression analysis dimaksudkan untuk mengukurtingkat pengaruh motivasi dan disiplin kerjatehadap produktivitas kerja dengan hasil berikut ini:

Tabel 3

Coefficients $^{\mathrm{a}}$

\begin{tabular}{llrrrrr}
\hline Model & \multicolumn{2}{c}{$\begin{array}{c}\text { Unstandardized } \\
\text { Coefficients } \\
\text { B }\end{array}$} & $\begin{array}{c}\text { Standardized } \\
\text { Coefficients } \\
\text { Beta }\end{array}$ & T & Sig. \\
\hline $\mathbf{1}$ & (Constant) & 20,956 & 3,896 & & 5,379 &, 000 \\
& Motivasi &, 334 &, 062 &, 513 & 5,407 &, 000 \\
& Disiplin Kerja &, 133 &, 089 &, 141 & 1,488 &, 141 \\
\hline
\end{tabular}

a. Dependent Variable: Produktivitas Kerja

Sumber: Hasil olah IBM SPSS Statistic 24, 2021

Diperoleh persamaan regresi ganda: $\mathrm{Y}=20,956+0,334 \mathrm{x}_{1}+0,133 \mathrm{x}_{2}$. sehingga:

- Konstanta 20,956; artinya bila motivasi $\left({ }_{x 1}\right)$ dan disiplin kerja $\left(\mathrm{x}_{2}\right)$ nol, maka produktivitas kerja bernilai 20,956.

- Nilai koefisien variabel motivasi $\left(\mathrm{x}_{1}\right)=0,334$; maknanya bila variabel independen lain konstan dan motivasi $\left(\mathrm{x}_{1}\right)$ naik 1 skor, produktivitas kerja (y) naik 0,334 skor. Koefisien positif artinya terdapat hubungan positif motivasi $\left(\mathrm{x}_{1}\right)$ terhadap produktivitas kerja (y), bila motivasi pegawai naik maka produktivitas juga akan naik.

- Nilai koefisien disiplin kerja $\left(\mathrm{x}_{2}\right)=0,133$; maknanyabila variabel independen lain konstanserta disiplin kerja $\left(\mathrm{x}_{2}\right)$ naik 1 skor, maka produktivitas kerja (y) naik 0,133 skor. Sebaliknya, biladisiplin kerja $\left(\mathrm{x}_{2}\right)$ turun 1 skor, produktitivas kerja (y) turun 0,133 skor.

\section{Analisis Koefisien Determinan}

Berdasarkan output uji koefisien determinan, pengaruhx $x_{1}$ dan $\mathrm{x}_{2}$ terhadap ydisajikan pada tabel berikut:

Tabel 4

\begin{tabular}{lrrrr}
\multicolumn{5}{c}{ Model Summary } \\
\hline Model & R & R Square & Adjusted R Square & Std. Error of the Estimate \\
\hline 1 &, $555^{\mathrm{a}}$ &, 307 &, 290 & 3,471 \\
\hline
\end{tabular}

a. Predictors: (Constant), Disiplin Kerja, Motivasi

b. Dependent Variable: Produktivitas Kerja

Sumber: Data Hasil IBM SPSS Statistic 24, 2021

Tabel 4 menunjukkan nilai koefisien determinan $(R$ Square $)=0,307(30,7 \%)$ sehingga produktivitas kerja (y) mampudijabarkan oleh motivasi $\left(\mathrm{x}_{1}\right)$ dan disiplin kerja $\left(\mathrm{x}_{2}\right)$ sebesar $30,7 \%$, dan $69,3 \%$ sisanya dijabarkan faktordiluar penelitian contohnya: pendidikan, sikap, etika kerja, kesehatan, keterampilan, perkembangan teknologi pendapatan, jaminan sosial, suasana kerja, fasilitaspendukung produksi,manajemen dan kesempatan berprestasi. 


\section{Uji Hipotesis}

Hipotesis penelitian yaitu ada pengaruh signifikan motivasi dan disiplin kerja terhadap produktivitas kerja pegawai Dinas Perkebunan Musi Banyuasin, baik bersama maupun parsial merupakan hipotesis. Hasil Uji serentak (uji F) untuk menjawab hipotesis yaitu:

Tabel 5

Hasil Uji F (Uji Serentak)

ANOVA $^{\mathrm{a}}$

\begin{tabular}{llrrrrr}
\hline & Model & \multicolumn{1}{c}{ Sum of } & Df & Mean Square & \multicolumn{1}{c}{ F } & \multirow{2}{*}{ Sig. } \\
\hline 1 & Regression & 422,610 & 2 & 211,305 & 17,539 & \multirow{2}{*}{$000^{\mathrm{b}}$} \\
& Residual & 951,792 & 79 & 12,048 & & \\
& Total & 1374,402 & 81 & & & \\
\hline
\end{tabular}

a. Dependent Variable: Produktivitas Kerja

b. Predictors: (Constant), Disiplin Kerja, Motivasi

Sumber: Data Hasil IBM SPSS Statistic 24, 2021

Diperoleh $F_{\text {hitung }}=17,539$ pada pengujian variabel motivasi $\left(\mathrm{x}_{1}\right)$ dan disiplin kerja $\left(\mathrm{x}_{2}\right)$ terhadap produktivitas kerja $(\mathrm{y})$, pada $\alpha=5 \%$, dk penyebut $=79$, dk pembilang $(\mathrm{k}=2)$ $= \pm 3,112$ diperoleh $F_{\text {tabel }}(3,112)$ sehingga diperoleh $F_{\text {hitung }}>F_{\text {tabel }}$, sehingga ada pengaruh simultan antara motivasi dan disiplin kerja terhadap produktivitas kerja pegawai Dinas Perkebunan Musi Banyuasin.

Nilai signifikan $(\operatorname{Sig} F)=0,000<\alpha(0,05)$ sehingga terdapat pengaruh signifikan motivasi $\left(\mathrm{x}_{1}\right)$ dan disiplin kerja $\left(\mathrm{x}_{2}\right)$ secara simultan terhadap produktivitas kerja $(\mathrm{y})$ pegawai Dinas Perkebunan Kabupaten Musi Banyuasin.

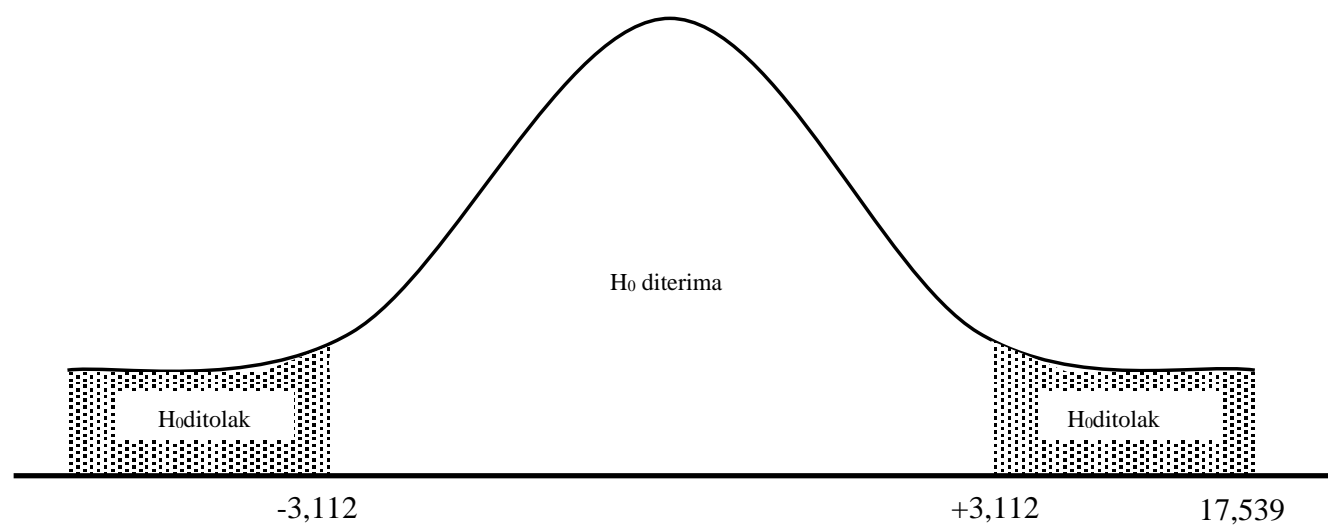

Gambar 2

Kurva Uji Serentak

Kurva uji tersebut menunjukkan bahwa nilai $F_{\text {hitung masuk ke dalam area }}$ penolakan hipotesis sehingga bila motivasi dan disiplin kerja naik, maka produktivitas kerja pegawai juga akan naik.

Uji parsial dilakukan untuk mengetahui pengaruh signifikan motivasi dan disiplin kerja secara parsial terhadap produktivitas kerja Dinas Perkebunan Kabupaten Musi 
Banyuasin sebagaimana disajikan dalam tabel 3. Pada $\alpha=5 \%$, $\mathrm{df}=82-2-1=79$, nilai $\mathrm{t}_{\text {tabel }}= \pm 1,991$, maka penulis dapat menjelaskan hasil uji parsial yaitu:

1) Pengaruh motivasi $\left(\mathrm{x}_{1}\right)$ terhadap produktivitas kerja $(\mathrm{y})$

Diperoleh $t_{\text {hitung }}(5,407)>t_{\text {tabel }}(1,991)$, makaada pengaruh parsial motivasi $\left(x_{1}\right)$ terhadap produktivitas kerja (y) Dinas Perkebunan Kabupaten Musi Banyuasin.

Sig $\mathrm{t}=0,000<\alpha$, bermakna ada pengaruh parsialsignifikan motivasi $\left(\mathrm{x}_{1}\right)$ terhadap produktivitas kerja $(\mathrm{y})$

2) Pengaruh disiplin kerja $\left(\mathrm{x}_{2}\right)$ terhadap produktivitas kerja $(\mathrm{y})$

Diperoleh $\mathrm{t}_{\text {hitung }}(1,488)<\mathrm{t}_{\text {tabel }}(1,991)$ sehingga tidakterdapat pengaruh parsial antara disiplin kerja $\left(\mathrm{x}_{2}\right)$ terhadap produktivitas kerja (y) Dinas Perkebunan Kabupaten Musi Banyuasin dengan $\operatorname{Sig} \mathrm{t}(0,141)>$ aartinyadisiplin kerja $\left(\mathrm{x}_{2}\right)$ secara parsial tidak berpengaruh signifikanpada produktivitas kerja $(\mathrm{y})$

\section{Pembahasan Hasil Penelitian}

Pengaruh Motivasi $\left(\mathrm{x}_{1}\right)$ dan Disiplin Kerja $\left(\mathrm{x}_{2}\right)$ secara bersama-sama terhadap Produktivitas Kerja (y)

Hasil uji serentak diketahui ada pengaruh positif signifikan motivasi $\left(\mathrm{x}_{1}\right)$ dan disiplin kerja $\left(\mathrm{x}_{2}\right)$ secara simultanpada produktivitas kerja (y) pegawai Dinas Perkebunan Kabupaten Musi Banyuasin. Sehingga motivasi dan disiplin kerja membawa dampak cukup besar pada produktivitas kerja pegawai.

Kondisi ini sesuaidengan kajianKatarina dan Kusumayadi (2021), yakni motivasi dan disiplin kerja secara simultanberpengaruh positif signifikan pada produktivitas kerja CV. Makmur Jaya Abadi.

Pejabat struktural Dinas Perkebunan Kabupaten Musi Banyuasin hendaknya menaruh perhatian terhadap variabel bebas penelitian ini untukmeningkatkan produktivitas kerja pegawai, terutama pegawai dengantingkat motivasi dan disiplin yang masih rendah.

Namun di balik itu semua, 30,7\% produktivitas kerja pegawai dapat dijabarkan melalui motivasi dan disiplin kerja, dan 69,3\% sisanya dijbarkan faktor diluar penelitian. Sehingga perlu dilakukan penelitian lanjutan untuk mengkaji berbagai faktor pendukungproduktivitas kerja.

\section{Pengaruh Motivasi $\left(\mathrm{x}_{1}\right)$ secara parsial terhadap Produktivitas Kerja $(\mathbf{y})$}

Hasil uji menghasilkan nilai koefisien regresi 0,334 artinya motivasi berpengaruh positif pada produktivitas kerja sebesar 33,4\%. Berdasarkan Hasil uji $t$ diketahuiadapengaruh signifikan motivasi secara parsial pada produktivitas kerja pegawai. Motivasi berkontribusi cukup besar dan berpengaruh pula terhadap produktivitas kerja pegawai. Kebutuhan akan berprestasi, berafiliasi dan berkuasa bisa memotivasi pegawai dalam bekerja, sehingga akan meningkatkan produktivitas kerjanya. Pegawai yang termotivasi dalam bekerja merupakan pegawai yang ideal pada suatu perangkat daerah.

Penelitian Laksmiari (2019) menunjukkan bahwa50,8\% produktivitas kerja pegawaiPT Teh Teratai Desa Patemon Serit dipengaruhi oleh motivasi kerja. Namun sedikit berbeda dengan Rampisela dan Lumintang (2020) bahwa tidak ada pengaruh signifikan motivasi terhadap produktifitas pegawai PT. Dayna Cipta.

\section{Pengaruh Disiplin Kerja $\left(\mathbf{x}_{2}\right)$ secara parsial terhadap Produktivitas Kerja $(\mathbf{y})$}

Diperoleh koefisien regresi 0,133 artinya13,3\% produktivitas kerja dipengaruhi disiplin kerja. Disiplin kerja parsial tidakmempunyai pengaruh parsial yang signifikan terhadap produktivitas kerja. Disiplin kerja berkontribusi kecil pada produktivitas. Pegawai dengan disiplin kerja minim, tidak mampu menghasilkan produk yang baik. 
Disiplin kerja yang diterapkan pada Dinas Perkebunan Kabupaten Musi Banyuasin belum menerapkan sepenuhnya teori Stewart dan Brown (2011:272) bahwadiscipline isorganizational efforts to correct improper behavior of employess.

Hasil ini selaras dengan kajian Cahyadi (2017),bahwa disiplin kerja tidak berpengaruh parsial pada produktivitas pegawai PT.Thamrin Brother's Palembang. Sementara itu, Saleh dan Utomo (2018) mengungkap disiplin kerja berpengaruh positif tidak signifikan pada produktivitas pegawai produksi PT. Inko Java Semarang. Kontras dengan penelitian Marsih dan Swarga (2020),yaitu disiplin kerja berpengaruh positif signifikanpada produktivitas kerja Kantor Kecamatan Sungai Lilin, Musi Banyuasin.

\section{KESIMPULAN}

Penulis dapat menyimpulkan bahwa:

1. Terdapat pengaruh bersama yang positif dan signifikan antara motivasi serta disiplin kerja terhadap produktivitas kerja pegawai Dinas Perkebunan Kabupaten Musi Banyuasin.

2. Terdapat pengaruh parsial positif dan signifikan motivasi terhadap produktivitas kerja pegawai Dinas Perkebunan Kabupaten Musi Banyuasin.

3. Tidak terdapat pengaruh parsial signifikandisiplin kerja terhadap produktivitas kerja pegawai Dinas Perkebunan Kabupaten Musi Banyuasin.

\section{DAFTAR PUSTAKA}

Ayu, Devi K, Sinaulan, Jeffry H. (2018). Pengaruh Insentif, Disiplin Kerja terhadap Kinerja Karyawan pada PT Bintang Satoe Doea. Jurnal Ekonomi, Vol. 20, No. 3, 373-383.

Cahyadi, Muhammad S., (2017). Pengaruh Pelatihan Kerja, Disiplin Kerja Karyawan terhadap Produktivitas Kerja Karyawan PT. Thamrin Palembang. Skripsi: Universitas Muhammadiyah Palembang.

Kartika, Putu \&Khaerana. (2019). Pengaruh Kompetensi, Kompensasi terhadap Produktivitas Kerja Karyawan PT. BRI Kacab Palopo. JEMMA: Journal of Economic, Management and Accounting, Vol. 2, No. 2, 38-44.

Katarina, Kusumayadi F. (2021). Pengaruh Motivasi Kerja dan Disiplin Kerja terhadap Produktivitas Karyawan CV. Makmur Jaya AbadiBima. Jurnal Inovasi Penelitian, Vol. 2, No. 1, 199-204.

Laksmiari, Putu Pradita. (2019). Pengaruh Motivasi Kerja terhadap Produktivitas Kerja Karyawan PT Teh Bunga Teratai Desa Patemon serrit. Jurnal Pendidikan Ekonomi Undiksha, Vo. 11, No. 1, 54-63.

Machali, Imam. (2015). Statistik Mudah, Menggunakan SPSS Alat Bantu Statistik. Yogyakarta: Lembaga Lada Kata.

Marsih, Yeni, Swarga\&Utas. (2020). Pengaruh Disiplin Kerja terhadap Produktivitas Kerja Kantor Kecamatan Sungai Lilin, Musi Banyuasin. Jurnal Manajemen Kompeten, Vol. 3, No. 2, 70-84.

Mathis, Robert L. dan Jackson, John H. (2011). Human Resource Management, $13^{\text {th }}$ Edition. USA: South-Western Cengage Learning.

Mustika, Amalia, et al. (2020). Pengantar Bisnis. Bandung: Widina Bhakti Persada.

Oemar, Usailan, Alamsyah, R., Rio. (2018). Pengaruh Program Keselamatan Kerja terhadap Produktivitas PT. Musi Banyuasin Indah. Jurnal Manajemen Kompeten, Vol. 1, No. 1, 88-101.

Priyatno, Duwi. (2014). SPSS 22: Pengolahan Data Terpraktis. Yogyakarta: Andi.

Rampisela, Virginia A. J.\&Lumintang. (2020). Pengaruh Motivasi Kerja, Lingkungan Kerja dan Upah terhadap Produktivitas Karyawan PT. Dayana Cipta.Jurnal 
EMBA: Jurnal Riset Ekonomi, Manajemen, Bisnis dan Akuntansi, Vol. 8, No. 1, 302-311.

Rivai, Veithzal \&Sagala, Ella Jauvani. (2010). Manajemen Sumber Daya Manusia Pada Perusahaan. Jakarta: Rajawali Pers.

Robbins, Stephen P. \& Mary C..(2009). Manajemen, Edisi ke-sepuluh.terjemah Bob Sabran dan Devri Barnadi Puterax. Jakarta: Erlangga.

Saleh, Abdul R.\&Hardi. 2018. Pengaruh Disiplin Kerja, Motivasi Kerja, Etos Kerja dan Lingkungan terhadap Produktivitas Karyawan Produksi PT. Inko Java Semarang. Jurnal Among Makarti, Journal of Economics \& Business, Vol. 11, No. 21, 28-50.

Sedarmayanti. (2017). Perencanaan dan Pengembangan SDM. Bandung: PT. Refika Aditama.

Stewart, Greg L. \& Brown, Kenneth G. (2011). Human Resource Management, Linking Strategy to Practice.USA: John W.\& Sons, Inc.

Sugiyono. 2019. Metode Penelitian Kualitatif, Kuantitatif, dan R\&D. Bandung: Alfabeta.

Supriyanto, Fery. (2019). Pengaruh Motivasi pada Produktivitas Kerja Dinas Perindustrian dan Perdagangan Musi Banyuasin. Jurnal Manajemen Kompeten, Vol. 2, No. 1, 29-45. 